\title{
Physicochemical Characterisation of Soils at the Gold Exploitation Sites of Bétaré-Oya District in Cameroon and Pollution Evaluation
}

\author{
Nchare Mominou*, Yaya Al Issah, Bahodock Sarki, Elvis Kah \\ School of Geology and Mining Engineering, University of Ngaoundere, Ngaoundere, Cameroon \\ Email: *nmominou@yahoo.com
}

How to cite this paper: Mominou, N., Al Issah, Y., Sarki, B. and Kah, E. (2018) Physicochemical Characterisation of Soils at the Gold Exploitation Sites of Bétaré-Oya District in Cameroon and Pollution Evaluation. Open Journal of Inorganic Chemistry, 8, 81-90.

https://doi.org/10.4236/ojic.2018.83007

Received: June 27, 2018

Accepted: July 28, 2018

Published: July 31, 2018

Copyright $\odot 2018$ by authors and Scientific Research Publishing Inc. This work is licensed under the Creative Commons Attribution International License (CC BY 4.0).

http://creativecommons.org/licenses/by/4.0/

\begin{abstract}
Physicochemical characterization and pollution evaluation were performed on six gold mining sites at the locality of Bétaré-Oya in Cameroon. Twelve samples of twenty two sampled show contamination with arsenic, nickel and lead. Granulometric analysis performed on all samples show a predominance of coarse particle $(>250 \mu \mathrm{m})$ and $\mathrm{PH}$ varying from 5.4 to 7 . The pollution index and pollution load index show that primary gold exploitation site of Mbal, Nakayo and Kpawara are contaminated. The highest pollution index is recorded on releases from the primary gold mining sites of Mbal, Kpawara and Nyondéré, which means that one must have a watchful eye to the discharges produced by primary gold mining. Sorting the samples in descending order of pollution index yields: $\mathrm{Mb} 3>\mathrm{Kp} 1>\mathrm{Kp} 2>\mathrm{Mb} 2>\mathrm{Mb} 1>\mathrm{Mb} 4>$ Kp3 $>$ Na5; meaning that special emphasis should be placed on the monitoring of wash sludge such as those from the Mbal site (Mb3), where pollution index is equal to 36.29 , as well as washed and waste rock.
\end{abstract}

\section{Keywords}

Bétaré-Oya, Goldmining, Pollution Index, Contamination

\section{Introduction}

Growing industrialization throughout the world has been accompanied by the extraction and distribution of mineral substances from their natural deposits. In the process of mining, heavier and larger particles are directly discharged into natural depressions and consequently, many kinds of risk elements are introduced into the environment, which cause serious environmental problems [1] [2] [3]. These harmful substances introduced into the environment have many 
adverse effects on human health, biological systems, agricultural productivity and natural ecosystem [4]. Environmental pollution by heavy metals has become a question of public concern considering their negative consequences. It produces substances whose existence poses major threats to quality living and existence of man and animals when it is above allowable limits [5]. Originating from small scale and even abandoned mine, all of these go a long way to contaminate streams and sediment as well as agricultural products with high concentrations of toxic metals [6]. This could result in metal poisoning in areas where water from such stream serves for some domestic use. Evaluation and characterization of the pollution orchestrated by heavy metals near mine had been a topic of concern within the scientific community in recent years.

This study focuses in investigating the potential sources of trace elements or heavy metals contamination and the evaluation of pollution potential in Bétaré-Oya mining site, in Cameroon.

\section{Materials and Methods}

\subsection{Materials}

Global Positioning System (GPS), was used to locate the sampling point. Fluorescence X (XRF) was used to conduct chemical analysis and a column of Sieves for granulometric analysis.

\subsection{Methods}

\subsubsection{Sampling}

Stratified random sampling was used in this study [7], it is a strategy based not only on a statistical approach [8], but where, in addition, the studied area is divided into homogeneous entities, called strata. We identify three strata on each of the sites, namely the waste rock stratum, the sand gravel stratum and the soil and sediment stratum. Sampling was carried out on six sites, namely Mbal, Kpawara, Nyondere, Lom, Nakoyo and 2 reference points where no mining activities are done. Coordinates of sites sampled are shown in Table 1.

\subsubsection{Evaluation of Soil Contamination}

1) Pollution index

The Soil Pollution Index (PI) is a concept introduced in many studies to identify multi-elements contamination that results in increased metal toxicity [9] [10] [11]. This is a criterion for assessing the overall toxicity of contaminated soil. It is calculated from the average ratio of metal concentrations in soil samples to limiting guideline values. These limit values correspond to the tolerable levels in soil suggested by Kloke [12]; when PI $<1$, the soil is not polluted, whereas for PI $>1$, the soil is polluted.

2) Pollution load index.

The degree of pollution of heavy metals in affected soils was assessed and compared through the Pollution Load Index [13]. This index is based on the 
Table 1. Coordinates of sites sampled.

\begin{tabular}{|c|c|c|c|c|}
\hline $\mathrm{N}^{\circ}$ & Code & Station & Origin & Coordinates \\
\hline 1 & Ref1 & \multirow{2}{*}{ Reference } & \multirow{2}{*}{ Bare ground } & N05.57267 E014.08759 \\
\hline 2 & Ref2 & & & N05.57867 E014.09369 \\
\hline 3 & Ny1 & \multirow[b]{2}{*}{ Nyondere } & Washed gravel & N05.59015 E014.10286 \\
\hline 4 & Ny2 & & Sediments & N05.59250 E014.10362 \\
\hline 5 & Mb1 & \multirow{7}{*}{ Mbal } & Sterile & N05.57760 E01407769 \\
\hline 6 & $\mathrm{Mb} 2$ & & Washed sand & N05.57810 E014.07627 \\
\hline 7 & $\mathrm{Mb} 3$ & & Wash mud & N05.57810 E014.07627 \\
\hline 8 & $\mathrm{Mb} 4$ & & Bare ground & N05.57852 E014.07581 \\
\hline 9 & Mb5 & & Sterile & N05.57823 E014.07482 \\
\hline 10 & Mb6 & & Washed gravel & N05.57809 E014.07482 \\
\hline 11 & $\mathrm{Mb} 7$ & & Sediments & N05.58100 E014.07374 \\
\hline 12 & $\mathrm{Na} 1$ & \multirow{5}{*}{ Nakoyo } & Waste solid & N05.54353 E014.06265 \\
\hline 13 & $\mathrm{Na} 2$ & & Washed sand & N05.53915 E014.06265 \\
\hline 14 & $\mathrm{Na} 3$ & & Bare ground & N05.53925 E014.06152 \\
\hline 15 & $\mathrm{Na} 4$ & & Washed mud & N05.53959 E014.06273 \\
\hline 16 & $\mathrm{Na} 5$ & & Washed gravel & N05.53897 E014.06008 \\
\hline 17 & Kp1 & \multirow{3}{*}{ Kpawara } & Washed gravel & N05.58255 E014.09499 \\
\hline 18 & $\mathrm{Kp} 2$ & & Bare ground & N05.58258 E014.09499 \\
\hline 19 & $\mathrm{Kp} 3$ & & Sterile & N05.58378 E014.09534 \\
\hline 20 & Lo1 & \multirow{3}{*}{ Lom } & Sterile & N05.63922 E014.09614 \\
\hline 21 & Lo2 & & Sterile & N05.63962 E014.09577 \\
\hline 22 & Lo3 & & Bare ground & N05.63847 E014.10824 \\
\hline
\end{tabular}

values of the concentration factors of each metal $(C F i)$ in the soil. The concentration factor is the ratio of the concentration of each metal in the soil to the value of the geochemical background (natural concentration of metal in the soil) of the same metal. The latter was assimilated in our study to the average concentration of the heavy metal in the reference samples. For each site sampled, the pollution load index $(P L I)$ is calculated by the formula:

$$
P L I=\sqrt{C F i \times C F j \times \cdots \times C F_{n}} .
$$

$C F i$ is equal to the concentration of metal $i$ over a geochemical background of metal $i$. The pollution load index ( $P L I)$ greater than 1 symbolizes pollution.

\section{Results and Interpretations}

\subsection{Physicochemical Characterization}

\subsubsection{Particle Size Analysis}

1) Sterile 
The results of the particle size analysis performed on the $\mathrm{Mb} 1, \mathrm{Mb} 5, \mathrm{Kp} 3$ and Lo1 sterile samples are presented in Figure 1.

From Figure 1, we can see that all the curves have a similar profile, marked by a dominance of coarse particles $(>250 \mu \mathrm{m})$ with respectively $74.32 \%$ for $\mathrm{Mb} 1$, $70.7 \%$ for $\mathrm{Mb} 5,84.88 \%$ for $\mathrm{Kp} 3$ and $90.91 \%$ for Lo1. This dominance of the coarse fraction is explained by the strong presence of lateritic gravel in the sterile. This could result in a difficult transport of this material, which can certainly reduce the mobility of heavy metals to environmental receptors such as soil. Moreover the strong presence of coarse fractions in these materials shows that the specific surface of these materials is low, meaning that the area available for metals adsorption becomes low, since the mass available for metals adsorption is larger for fine particles than for coarse particles [11]. Finally the dominance of the coarse fraction clearly indicates a weak presence of clay, which can reduce the adsorption of the heavy metals.

2) Discharged gravels

Figure 2 give the results of the particle size analysis performed on discharged gravel or waste washed gravel samples Ny2, Ny3, Mb6 and Lo2. Curves with similar profiles are also observed, with a strong dominance of coarse particles. Sample Ny2, has $96.25 \%$ coarse particles, $85.54 \%$ for Ny3, 70.99\% for Mb6 and $88.94 \%$ for Lo2. This presages a low particle transport and a low adsorption of heavy metals as for the case of sterile. The low presence of clay may decrease the adsorption of metals.

3) Washed sand

The results of the particle size analysis performed on washed sand samples $\mathrm{Mb} 2, \mathrm{Na} 2, \mathrm{Na} 5$ and $\mathrm{Kp} 1$ are shown in Figure 3.

In contrast to sterile and gravel samples, primary gold's washed sand has more fine particles with $90.68 \%$ of particles smaller than $800 \mu \mathrm{m}$ for Na5, $78.32 \%$ for

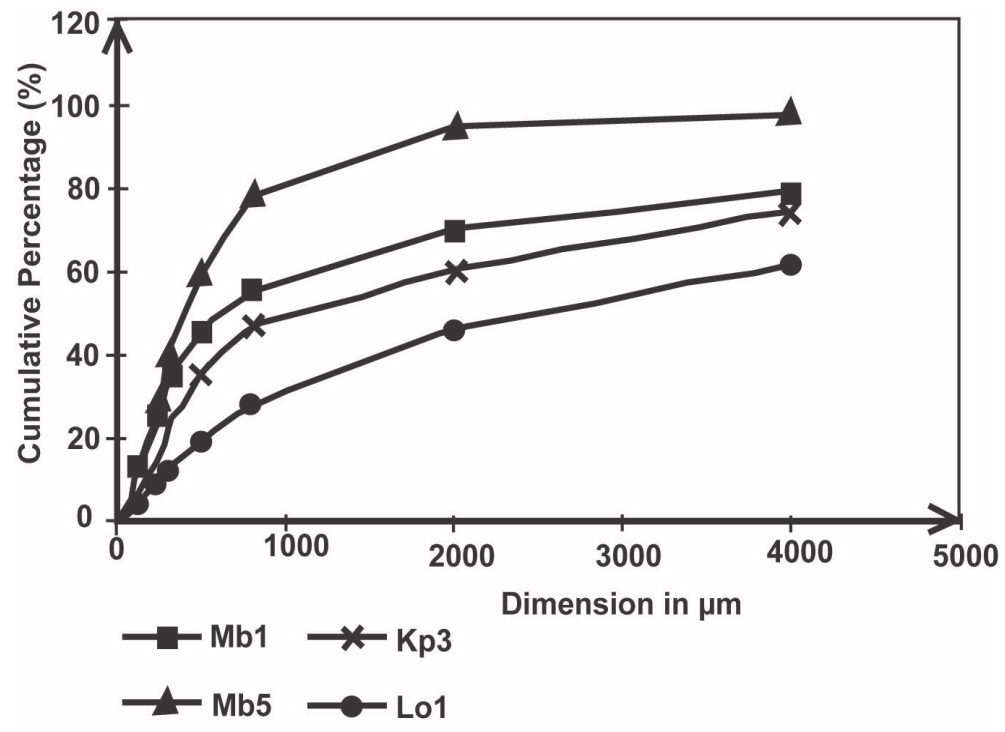

Figure 1. Sterile granulometric curve. 




Figure 2. Waste washed gravel granuometric curve.



Figure 3. Waste washed sand granulometric curve.

$\mathrm{Kp} 1,34.15 \%$ for $\mathrm{Mb} 2$ and 27.92\% for $\mathrm{Na} 2$, which predict easy transport by water and wind. The clay fraction is low in all samples, which could decrease the adsorption of heavy metals.

4) $\mathrm{pH}$ value

The $\mathrm{pH}$ value of samples analyzed is given in Figure 4.

It is noted that the $\mathrm{pH}$ value varies between 5.4 and 7.2 for all samples, which means that sterile, sediments and soils are slightly acidic and even neutral for some. The $\mathrm{pH}$ influences the mobility and bioavailability of heavy metals. Heavy metals can be mobilized when environmental conditions, especially $\mathrm{pH}$, change [14]. Thus, when the $\mathrm{pH}$ decreases, desorption or dissolution processes will tend to lead to the release of metal cations from the sterile and washed sand which are the sources of heavy metals to the dissolved phase, while an alkaline $\mathrm{pH}$ 




Figure 4. $\mathrm{pH}$ variation in function of sample site.

promotes the precipitation of metals and their complexes. Since the $\mathrm{pH}$ is slightly acidic for all the sites studied, there should be a release of the heavy metals into the environment.

\subsubsection{Chemical Analysis}

The results of the chemical analysis on sterile and soil samples are summarized in Table 2 and Table 3 respectively.

The arsenic content of gangue samples Mb1, Mb2, Mb3, Mb5 from the Mbal site, Na5 from Nakoyo site, Kp1, Kp3 from Kpawara site and Lo1 from Lom, is greater than the geochemical background of the locality and is also higher than the normal global average of the uncontaminated soils [10]. The highest levels of arsenic are found at Mbal, Kpawara and Nakoyo, which are all primary gold mining sites. This is justified by the strong presence of arsenopyrite minerals in the veins, which are exposed during mining. Arsenic content in soil and sediment samples is greater than 6 ppm, the normal global average of Bowen's uncontaminated soils [10].

The strong presence of Arsenic in the soils of Kpawara and Mbalgold mining sites may be justified by the presence of gold veins rich in arsenopyrite on these sites. The relative arsenic content confirmed the migration of arsenic not only from the gangue to the soil, but also from free water collected upstream of these primary gold mining sites. From Table 3 we can see that samples Mb4 and Kp2 have high content of Arsenic, Nickel and Lead.

\subsubsection{Evaluation of the Contamination}

To evaluate multi-element contamination of soils by metals, assessment tools such as the pollution index and the pollution load index are used.

1) Pollution Index (PI)

Contamination by heavy metals on soils' surface, particularly in mine sites, is 
Table 2. Chemical analysis of the gangue.

\begin{tabular}{|c|c|c|c|c|c|c|c|c|c|c|}
\hline \multicolumn{11}{|c|}{ Content (ppm) } \\
\hline Sample & As & $\mathrm{Cr}$ & $\mathrm{Cu}$ & $\mathrm{Ni}$ & $\mathrm{Pb}$ & $\mathrm{Zn}$ & $\mathrm{Cd}$ & $\mathrm{Hg}$ & PI & PLI \\
\hline Ny1 & 2.4 & 70.7 & 0.9 & 46.7 & 0.0 & 44.3 & & & 0.3 & 0.0 \\
\hline Mb1 & 340.7 & 92.4 & 44.9 & 49.9 & 817.4 & 15.9 & & & 11.2 & 7593.9 \\
\hline $\mathrm{Mb} 2$ & 345.3 & 70.5 & 49.1 & 36.5 & 1073.1 & 9.6 & & & 11.7 & 3723.6 \\
\hline Mb3 & 111.3 & 78.7 & 95.2 & 47.1 & 2981.7 & 18.9 & & & 36.3 & 18367.6 \\
\hline Mb4 & 16.2 & 52.7 & 7.3 & 40.3 & 0.0 & 10.8 & & & 0.7 & 0.0 \\
\hline Mb6 & 4.8 & 48.4 & 0.0 & 37.3 & 0.0 & 15.1 & & & 0.3 & 0.0 \\
\hline Nb7 & 15.1 & 20.5 & 1.3 & 25.4 & 96.3 & 10.8 & & & 0.7 & 0.1 \\
\hline $\mathrm{Na} 2$ & 0.4 & 53.6 & 5.4 & 29.4 & 0.0 & 9.8 & $<\mathrm{DL}$ & $<\mathrm{DL}$ & 0.2 & 0.0 \\
\hline $\mathrm{Na} 3$ & 2.8 & 32.3 & 5.1 & 38.9 & 0.0 & 26.7 & & & 0.3 & 0.0 \\
\hline $\mathrm{Na} 4$ & 3.2 & 47.8 & 23.9 & 40.9 & 0.0 & 13.1 & & & 0.3 & 0.0 \\
\hline $\mathrm{Na} 5$ & 75.4 & 53.4 & 5.6 & 28.1 & 376.1 & 9.3 & & & 2.9 & 18.3 \\
\hline $\mathrm{Kp} 1$ & 750.2 & 33.7 & 60.8 & 18.7 & 2619.1 & 10.6 & & & 25.4 & 6562.2 \\
\hline Kp3 & 151.5 & 84.2 & 46.2 & 48.1 & 558.3 & 12.4 & & & 5.5 & 1619.3 \\
\hline Lo1 & 8.2 & 80.1 & 20.7 & 53.2 & 0.0 & 12.7 & & & 0.5 & 0.0 \\
\hline Lo2 & 1.02 & 36.6 & 0.0 & 44.7 & 0.0 & 55.2 & & & 0.2 & 0.0 \\
\hline
\end{tabular}

PI: Pollution Index; PLI: Pollution Load Index; DL: Detection Limit.

Table 3. Chemical analysis of soils and sediments.

\begin{tabular}{|c|c|c|c|c|c|c|c|c|c|c|}
\hline \multicolumn{11}{|c|}{ Content (ppm) } \\
\hline Sample & As & $\mathrm{Cr}$ & $\mathrm{Cu}$ & $\mathrm{Ni}$ & $\mathrm{Pb}$ & $\mathrm{Zn}$ & $\mathrm{Cd}$ & $\mathrm{Hg}$ & PI & PLI \\
\hline Ref1 & 5.4 & 81.6 & 30.9 & 47.7 & 8.9 & 17.1 & & & 0.5 & 0.8 \\
\hline $\operatorname{Ref} 2$ & 3.6 & 69.8 & 19.8 & 27.5 & 0.0 & 10.9 & & & 0.3 & 0.0 \\
\hline FG & 4.5 & 75.7 & 25.4 & 37.6 & 4.5 & 14.0 & & & 0.4 & 1.0 \\
\hline Ny2 & 12.5 & 58.4 & 0.0 & 32.8 & 39.7 & 55.3 & & & 0.6 & 0.0 \\
\hline Mb4 & 216.0 & 75.3 & 47.8 & 55.1 & 513.1 & 20.2 & $<\mathrm{DL}$ & $<\mathrm{DL}$ & 7.2 & 3671.2 \\
\hline Mb7 & 15.1 & 20.5 & 1.3 & 25.4 & 96.3 & 10.8 & & & 0.7 & 0.1 \\
\hline $\mathrm{Nal}$ & 2.3 & 44.8 & 25.5 & 44.2 & 0.0 & 38.3 & & & 0.3 & 0.0 \\
\hline $\mathrm{Kp} 2$ & 368.8 & 67.1 & 31.6 & 32.7 & 1164.2 & 15.5 & & & 12.4 & 3813.7 \\
\hline Lo8 & 4.8 & 73.1 & 11.3 & 35.3 & 0.0 & 22.3 & & & 0.4 & 0.0 \\
\hline Bowen & 6.0 & 70.0 & 30.0 & 50.0 & 35.0 & 90.0 & 0.3 & & & \\
\hline AFNOR & & 150.0 & 100.0 & 150.0 & 100.0 & 300.0 & 2.0 & & & \\
\hline
\end{tabular}

PI: Pollution Index; PLI: Pollution Load Index; LD: Detection Limit. 
associated with a cocktail of contaminants rather than a single metal [15]. Thus, the concept of a pollution index makes it possible to identify the sites contaminated by metal so as to envisage an efficient solution through a good planning of the rehabilitation. After calculating the pollution index(PI) of our 22 samples, we realize that 8 samples namely $\mathrm{Mb} 1, \mathrm{Mb} 2, \mathrm{Mb} 3$ and Mb4 from Mbal exploitation site; Kp1, Kp2, Kp3 from Kpawara; and finally Na5 from Nakoyo have a pollution index greater than one (PI $>1)$, as shown in Figure 5. This means that these sites are contaminated and that it is already necessary to think of a strategy of rehabilitation.

We note that the highest pollution index were recorded on releases from the primary gold mining sites of Mbal, Kpawara and Nyondéré; which means that one must have a watchful eye to the discharges produced by primary gold mining. Sorting the samples in descending order of pollution index, yields $\mathrm{Mb3}>$ $\mathrm{Kp} 1>\mathrm{Kp} 2>\mathrm{Mb} 2>\mathrm{Mb} 1>\mathrm{Mb} 4>\mathrm{Kp} 3>\mathrm{Na}$; This means that special emphasis should be placed on the monitoring of washed sludge such as those from the Mbal site (Mb3) where PI is equal to 36.29 , as well as washed and waste rock. Finally, Arsenic, Nickel and Lead are present at high levels at 3 contaminated sites (Figure 6). The contents distribution of these elements shows an increase in the concentrations downstream the mine [15].

\section{Conclusion}

Analysis of Bétaré-Oya gold mining sites revealed a contamination by heavy metals at all primary gold mining sites; Sorting the samples in descending order of pollution index, yields Mb3 > Kp1 > Kp2 > Mb2 > Mb1 > Mb4 > Kp3 > Na5; This means that special emphasis should be placed on the monitoring of washed sludge such as those from the Mbal site (Mb3) where pollution index is equal to 36, 29 as well as washed and waste rock. These sites therefore present a risk of release and migration of heavy metals if there is any slight change in environmental conditions.



Figure 5. Pollution index of samples site. 


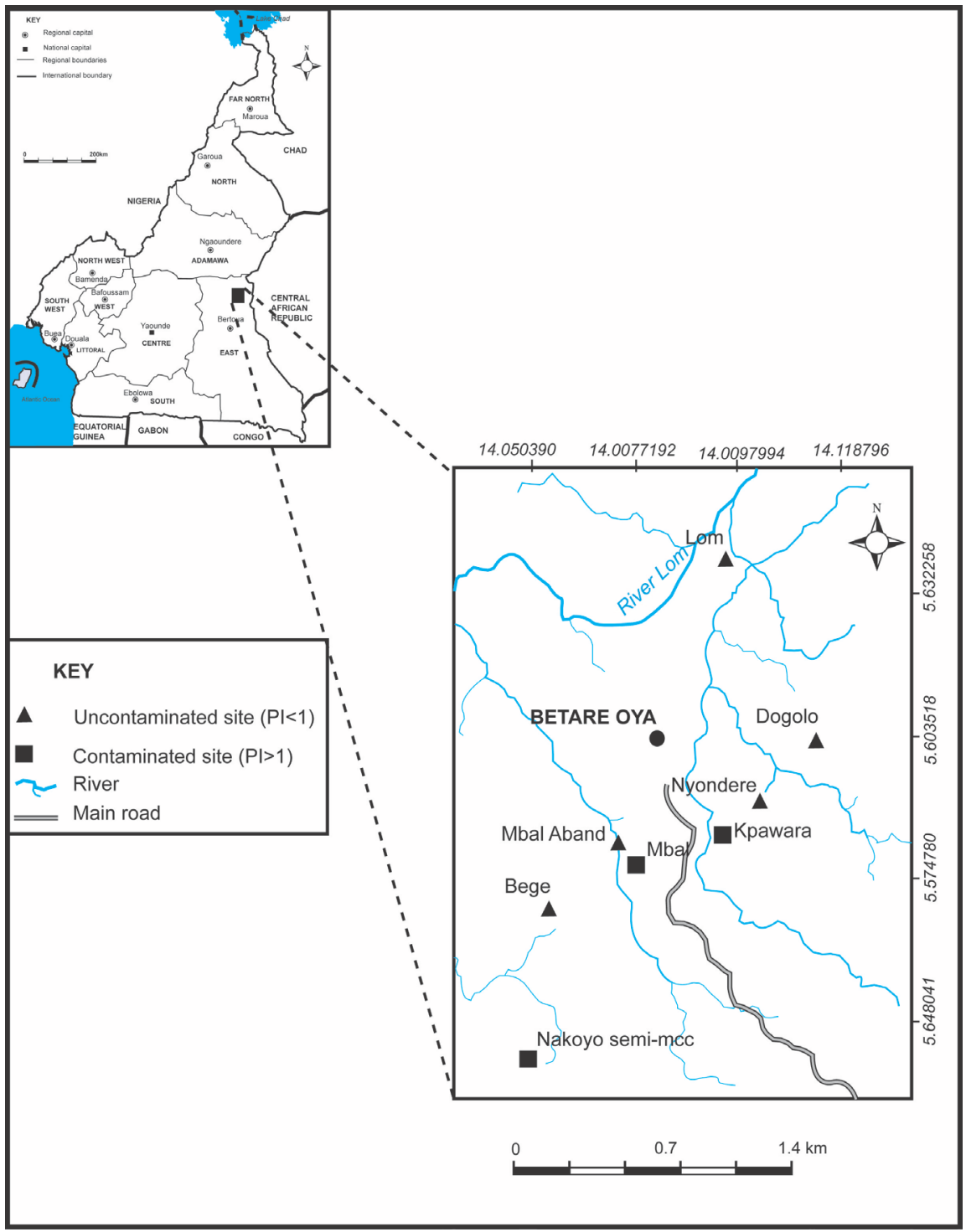

Figure 6. Contaminated sites in Bétaré-Oya.

\section{Acknowledgements}

This research project was done under the collaboration between the laboratory of extractive metallurgy of the School of Geology and Mining Engineering and the Institute for Local Mineral Resource Development. For the financial funding of this project, we thank Pr. Ngounouno, director of the School of Geology and Mining Engineering.

\section{Conflicts of Interest}

The authors declare no conflicts of interest regarding the publication of this paper.

\section{References}

[1] Barkouch, Y. and Pineau, A. (2016) Evaluation of the Impact of Mine Activity on 
Surrounding Soils of Draa Lasfar Mine in Marrakech-Morocco. African Journal of Environmental Science and Technology, 10, 44-49.

[2] Shahid, M., Islam, S.-U. and Mohammad, F. (2013) Recent Advancements in Natural Dye Applications: A Review. Journal of Cleaner Production, 53, 310-331. https://doi.org/10.1016/j.jclepro.2013.03.031

[3] Peter, A., De Carvalho, J. and Sharma, S. (2012) DNA Methylation Screening Identifies Driver Epigenetic Events of Cancer Cell Survival. Cancer Cell Journal, 21, 655-667. https://doi.org/10.1016/j.ccr.2012.03.045

[4] Mapanda, F., Mangwayana, E.N., Nyamangara, J. and Giller, K. (2005) The Effect of Long-Term Irrigation Using Wastewater on Heavy Metal Contents of Soils under Vegetables in Harare, Zimbabwe. Agriculture Ecosystems \& Environment, 107, 151-165. https://doi.org/10.1016/j.agee.2004.11.005

[5] Lujiza1, F.N. and Ogunfowokan, A.O. (2002) Trace Metal Pollution in Umtata River. Water $S A, 28,183-190$. https://doi.org/10.4314/wsa.v28i2.5160

[6] Hirsch, A., Lamparth, I., Groesser, T. and Karfunkel, H.R. (1994) Regiochemistry of Multiple Additions to the Fullerene Core. Journal of the American Chemical Society, 116, 9385-9386. https://doi.org/10.1021/ja00099a088

[7] BRGM (1993) Echantillonnage de sol pour caractérisation de pollution: Guide méthodologique. France, 17.

[8] Pierre, G. (1998) Echantillonnage, Techniques de l'Ingénieur. 23.

[9] Chon, H., Jung, M.C. and Ahn, J. (1998) Seasonal Variations and Chemical Forms of Heavy Metals in Soils and Dusts from the Satellite Cities of Seoul. Environmental Geochemistry and Health, 20, 77-86. https://doi.org/10.1023/A:1006593708464

[10] Bowen, H.J.M. (1979) Environmental Chemistry of the Elements. Academic Press, New York.

[11] Lee, C.G., Jung, M. and Chon, H. (2001) Heavy Metal Contamination in the Vicinity of the Daduk Au-Ag-Pb-Zn Mine in Korea. Applied Geochemistry, 16, 1377-1386. https://doi.org/10.1016/S0883-2927(01)00038-5

[12] Tomlinson. D., Wilson, J.G., Harris, C.R. and Jeffrey, D.W. (1980) Problems in the Assessment of Heavy-Metal Levels in Estuaries and the Formation of a Pollution Index. Helgoländer Meeresuntersuchungen, 33, 566-575. https://doi.org/10.1007/BF02414780

[13] Chiffoleau, I. and Truquet, J.F. (1994) Nouvelles méthodes de dosages des métaux traces dans les sédiments et les matières en suspension. Cah Agric, 7, 1-7.

[14] Lorenzo, F., Alonso, A., Pellicer, M.J., Pagés, J.L. and Pérez-Arlucea, M. (2007) Historical Analysis of Heavy Metal Pollution in Three Estuaries on the North Coast of Galicia (NW Spain). Environmental Geology, 52, 789-802. https://doi.org/10.1007/s00254-006-0516-6

[15] Axtmann, E.V. and Luoma, S.N. (1991) Large-Scale Distribution of Metal Contamination in the Fine-Grained Sediments of the Clark Fork River, Montana, U.S.A. Applied Geochemistry, 6, 75-88. https://doi.org/10.1016/0883-2927(91)90064-V 